\section{CarakaTanil \\ Journal of Sustainable Agriculture \\ ISSN 2613-9456 (Print) 2599-2570 (Online)}

\title{
Growth Evaluation of Banana cv. Barangan as the Effect of Trichoderma sp. and Covering Types during Acclimatization Process
}

\author{
Andre Sparta* and Deni Emilda \\ Indonesian Tropical Fruit Research Institute, Solok, West Sumatra, Indonesia \\ *Corresponding author: ansparra@gmail.com
}

\begin{abstract}
Acclimatization is one of the important processes in banana micro propagation before plantlets/ planting materials are ready to be cultivated in the field. Trichoderma sp. are well known as plant promoter fungi that can promote plant growth and increase survival rate of plantlets. The study was arranged in a Completely Randomized Factorial Design with two factors and four replications. The first factors was covering type i.e. 1) individual covering and 2) mass covering. The second factor was the proportion of Trichoderma addition into manure, namely a) manure without the addition of Trichoderma sp. (control), b) Trichoderma sp. : manure $=1: 400(\mathrm{w} / \mathrm{w}), \mathrm{c})$ Trichoderma $\mathrm{sp}$. : manure $=1: 800(\mathrm{w} / \mathrm{w})$ and d) Trichoderma $\mathrm{sp} .:$ manure $=1: 1,200(\mathrm{w} / \mathrm{w})$. The purpose of this study was to investigate the effect of Trichoderma sp. applications and covering types in the growth of banana plantlets $\mathrm{cv}$. Barangan during the acclimatization process. The results showed that the best treatment to induce plantlet growth during the acclimatization process was the addition of Trichoderma sp.: manure with $1: 400(\mathrm{w} / \mathrm{w})$ proportion and individual covering. The combination of Trichoderma sp. : manure with $1: 400(\mathrm{w} / \mathrm{w})$ proportion and individual covering produced plant height and leaf length $8.5 \mathrm{~cm}$ and $4.4 \mathrm{~cm}$, respectively, compared to the treatment without Trichoderma sp. addition that produced plantlets with $6.6 \mathrm{~cm}$ height and $3.4 \mathrm{~cm}$ leaf length. No significant interaction was shown between Trichoderma sp. proportions and covering types on leaf width, the number of leaves and root length parameters.
\end{abstract}

Keywords: acclimatization; banana; plant growth promoting fungi; Trichoderma sp.

Cite this as: Sparta, A., \& Emilda, D. (2020). Growth Evaluation of Banana cv. Barangan as the Effect of Trichoderma sp. and Covering Types during Acclimatization Process. Caraka Tani: Journal of Sustainable Agriculture, 35(2), 268-277. doi: http://dx.doi.org/10.20961/carakatani.v35i2.41191

\section{INTRODUCTION}

Banana is one of the important parts of diet for many people in the world, including in Indonesia (Hallam, 1995; Wong et al., 2017; Murunde et al., 2018; FAO, 2019). This commodity is counted as the second most important fruit trade in the world after citrus (Hallam, 1995; Ortas et al., 2017). Banana are produced in many places of the world, such as Asia, Africa, Europe, Oceania, Central America and South America and among those, Asia is the largest banana production area in the world (Lahav, 1995; FAO, 2019). The banana plant from family Musaceae is known as the common fruit plant that are grown and cultivated in many areas in Indonesia. Banana var Barangan is one of commercial banana cultivars in Indonesia that is mainly produced in Deli Serdang and Simalungun Regencies (Nainggolan et al., 1998). Many farmers choose this banana cultivar to be cultivated because of its commercial value. However, this cultivar is categorized as susceptible to Fusarium wilt disease (Emilda et al., 2020).

\footnotetext{
* Received for publication April 17, 2020

Accepted after corrections July 14, 2020
} 
Banana is propagated by vegetative propagation methods, such as conventional propagation and micro propagation by tissue culture. The mainly used banana conventional propagation method is direct separation of banana tillers aiming at planting and killing the growing point of banana corm to induce axillary buds. The conventional vegetative propagation methods have several disadvantages, such as limited number of tillers, difficulties in transportation due to the size of tillers and the risk of infection by Fusarium (Ortas et al., 2017; Wong et al., 2017). Micro propagation can overcome several limitations found on conventional vegetative propagation. Micro propagation can produce mass banana seedlings with smaller amount of planting materials within short periods of time and smaller size of plantlets/planting materials and thus it will be easier to mass transported. This method can also reduce the chance of getting infected by diseases (Tenkouano et al., 2006; Chandra et al., 2010; Ortas et al., 2017; Kumar et al., 2019).

Acclimatization is one of the important processes in plant micro propagation before plantlets/planting materials are ready to be cultivated in the field (Pospóšilová et al., 1999; Hazarika, 2003; Thomas et al., 2010). The purpose of acclimatization process is to establish plant condition from in vitro to field condition (Robinson and Sáuco, 2009). There would be sudden changes of temperature, humidity and light conditions between in vitro and the field conditions. The sudden changes in environmental conditions promote abiotic and biotic stresses and even reduce the survival rate of the plantlets (Hazarika, 2003; Ortas et al., 2017; Wong et al., 2017; Shah et al., 2019). Furthermore, micro propagation of plants in the in vitro conditions may trigger the anatomy, physiology and morphology abnormalities of plantlets (Pospóšilová et al., 1999; Gutiarrez-Miceli et al., 2008; Chandra et al., 2010). Therefore, the acclimatization is needed to promote a normal growth of these plantlets and increase their survival rates.

During acclimatization, several treatments are used in order to prepare better adaptation of the plantlets in the new environmental condition. Hardening process, medium composition and covering types are different among plant species and varieties (Gutiarrez-Miceli et al.,
2008; Winarto and Prama Yufdy, 2017; Shah et al., 2019). Covering the plant is an important step to reduce water loss during this process. Several plant species need transparent plastic and others use nylon mess covering types (Gutiarrez-Miceli et al., 2008; Winarto and Prama Yufdy, 2017). Some plants need single covering (one plant inside one cover) in order to survive, while the others can use mass covering.

Microbes play an important role in the acclimatization process of several plants (Pandey et al., 2000; Bag et al., 2001; Ortas et al., 2017; Shah et al., 2019). Dwarf Cavendish plantlets form mutualistic symbiosis with arbuscular mycorrhiza fungi to increase the plant growth and P-uptake (Ortas et al., 2017). Plantlets of Cymbidium aloifolium need to colonize with Piriformospora indica in order to increase their survival rate (Shah et al., 2019).

The application of several microbes, for example Trichoderma sp., are friendly to environment. Previous experiments showed that Trichoderma sp. could be a role model for sustainable agricultural practice (Singh et al., 2015; Al-Ani, 2018). These species are well known as plant growth promoting fungi (PGPF) and bio control agents for several soil borne diseases (Martínez-Medina et al., 2011; Barari, 2016; Khan et al., 2017; Castillo et al., 2019).

Trichoderma sp. can be used to increase the survival rate of plantlets during acclimatization in several plants. Gutiarrez-Miceli et al. (2008) stated that Trichoderma sp. increased the survival and growth rates of orchid plantlets Guarianthe skinnerii. Murunde et al. (2018) investigated the role of Trichoderma as plant growth promotor in Grand Naine and William Hybrid banana cultivars during weaning and potting stages. However, no information is obtained so far about the application of Trichoderma sp. during the acclimatization of banana plantlets cv. Barangan. The purpose of this study is to investigate the effect of Trichoderma sp. applications and covering types in the growth of banana plantlets cv. Barangan.

\section{MATERIALS AND METHOD}

\section{Experimental site}

The study was conducted in Aripan Experimental Station, Indonesian Tropical Fruit 
Research Institute, from January to August 2019. The experimental site is located at $0^{\circ} 44^{\prime} 17^{\prime \prime} \mathrm{S}$ and $100^{\circ} 37^{\prime} 20^{\prime \prime}$ E, approximately 425 meter above sea level in Solok Regency, West Sumatera Province, Indonesia. The means of annual temperature, rainfall and light time at this location are $24^{\circ} \mathrm{C}, 175 \mathrm{~mm}$ and 7 hours, respectively.

\section{Experimental design}

The study was arranged in a Completely Randomized Factorial Design with two factors and four replications. The first factor was covering type i.e. 1) individual covering and 2) mass covering. The second factor was the proportion of Trichoderma addition into manure, namely: a) manure without addition of Trichoderma sp. (control), b) Trichoderma sp. : manure = 1:400 (w/w), c) Trichoderma sp. : manure $=1: 800(\mathrm{w} / \mathrm{w})$ and d) Trichoderma $\mathrm{sp}$. : manure $=1: 1,200(\mathrm{w} / \mathrm{w})$.

\section{Plant material}

Banana cv. Barangan is one commercial banana cultivar that origins from North Sumatera Province, with Deli Serdang and Simalungun Regency as the production centers of this banana (Nainggolan et al., 1998). This cultivar is included in triploid group (AAA) (Poerba et al., 2018) with potential production around 7 ton ha ${ }^{-1}$.

\section{Preparation of planting material}

Banana plantlets cv. Barangan used in this study was obtained from tissue culture propagation. Six months before the acclimatization treatments, the explants obtained from banana corms were cultured. During the tissue culture period, the explants were sub-cultured four times in two different medium compositions. Media used in the initiation period were Murashige and Skoog (MS) medium (Murashige and Skoog, 1962) + 4 ppm Benzyl Amino Purin $(\mathrm{BAP})+2 \mathrm{ppm}$ Indole Acetic Acid (IAA). After that, these explants were sub-cultured in MS medium $+5 \mathrm{ppm}$ BAP +2 ppm IAA for three times. Banana plantlets with at least three leaflets were ready to be treated.

\section{Preparation of Trichoderma mixture}

Trichoderma isolate used in this study was obtained from Laboratory of Plant Protection, Indonesian Tropical Fruit Research Institute, Solok, West Sumatera. Trichoderma mixture was prepared two weeks before the acclimatization process started. Both of Trichoderma and manure were mixed together based on treatments and then kept in plastic bag for two weeks (Patent No. IDP 000037067, 2014). After two weeks, each combination was mixed with sterile soil and rice husk charcoal by comparison ratio of $2: 6: 1$ $(\mathrm{w} / \mathrm{w} / \mathrm{w})$. The combinations were collected and filled in each plastic pot.

\section{The treatments process}

Before the acclimatization process, the lid was removed from the bottle and the plantlets were separated from agar media into individuals and then washed in clean water. After that, all plantlets roots were removed neatly and dipped in fungicide for 15 minutes (Robinson and Sáuco, 2009). After that, plantlets were planted in plastic pots containing media with Trichoderma sp. proportion as stated previously and covered by transparent plastic cups or plastic sheets based on the treatments (individual covering or mass covering). Plantlets were maintained in same conditions during two weeks.

\section{Data collection}

The survival rates, plant height, leaf length, leaf width and number of leaves of plantlets were observed after two weeks in acclimatization process.

\section{Statistical analysis}

The data of survival rates, plant height, leaf length, leaf width and number of leaves were analyzed using software SPSS 17 software package (SPSS Inc., Chicago, Illinois, USA). Analysis of variance (ANOVA) was applied to test the experimental treatment effects, followed by Duncan New Multiple Range Test (DNMRT) at $p<0.05$ if there were significant differences between the treatments.

\section{RESULTS AND DISCUSSION}

The survival rates, plant height, leaf length, leaf width and number of leaves of these plantlets were determined after fourteen days. This experiment resulted in similar survival rates of banana plantlets cv. Barangan in two factor treatments (Table 1). Both covering types and Trichoderma proportions did not significantly affect the survival rates of banana plantlets $\mathrm{cv}$. Barangan. These treatments resulted in survival rates of banana plantlets var. Barangan, from $91.7 \%$ to $100 \%$. 
Table 1. The survival rates of banana plantlets cv. Barangan after two-week acclimatization on two covering types and four Trichoderma sp. proportions. The values in columns followed by the same letter are not significantly different at $p<0.05$

\begin{tabular}{lc}
\hline \multicolumn{1}{c}{ Treatments } & Survival rates (\%) \\
\hline Covering types & \\
- Individual covering & $\left.95.8 \pm 2.85 \mathrm{~ns}^{*}\right)$ \\
- Mass covering & $95.8 \pm 2.85$ \\
Trichoderma proportions & 100 \\
- Manure without Trichoderma addition & $95.8 \pm 4.17$ \\
- Trichoderma $:$ manure $=1: 400(\mathrm{w} / \mathrm{w})$ & $91.7 \pm 5.54$ \\
- Trichoderma $:$ manure $=1: 800(\mathrm{w} / \mathrm{w})$ & $95.8 \pm 4.17$ \\
- Trichoderma $:$ manure $=1: 1,200(\mathrm{w} / \mathrm{w})$ & $(-)$ \\
\hline \multicolumn{2}{c}{ Interaction }
\end{tabular}

Note: (-) showing no interaction, where ns means that the treatments given did not give significantly different survival rates among all treatments based on ANOVA Test at $p<0.05$; data are means of four replicates with standard error

Banana plantlets cv. Barangan at all treatments had higher survival rates. In most cases, the addition of bio control agent, such as Trichoderma sp., would provide better survival rates of plantlets during acclimatization (Gutiarrez-Miceli et al., 2008; Thomas et al., 2010). However, in this experiment, addition of Trichoderma sp. in medium composition did not affect the survival rates of banana plantlets. Probably, other factors, such as plantlet condition, environment condition and plantlet size, played their role in the survival rates of plantlets. Seed vigor and size determined the survival rates of papaya plantlets in acclimatization process (Damayanti et al., 2007).

In contrast with the survival rates, the treatments significantly affected the plant height, leaf length, leaf width, number of leaves and root length of banana plantlets (Figure 1, Table 2). The plantlet heights were significantly different between treatments at $p<0.05$ (Figure 1). The highest plantlet was found in the interaction treatment between Trichoderma: manure $=1$ : $800(\mathrm{w} / \mathrm{w})$ and individual covering $(9.7 \mathrm{~cm})$. However this result was not significantly different with the result shown in the treatment using Trichoderma sp. : manure $=1: 400(\mathrm{w} / \mathrm{w})$ with individual covering and mass covering.

The application of Trichoderma sp. in appropriate proportion had a beneficial effect on plant growth in acclimatization process. This microorganism showed its role as plant growth promoter. Orchid seedlings, Guarianthe skinnerii that inoculated with Trichoderma harzanium, grew 3.6 times higher than in the control treatment (Gutiarrez-Miceli et al., 2008). Kushwaha et al. (2019) also reported that the Indian ginseng grew 15-30\% higher on media with Trichoderma sp. compared to the control treatment.

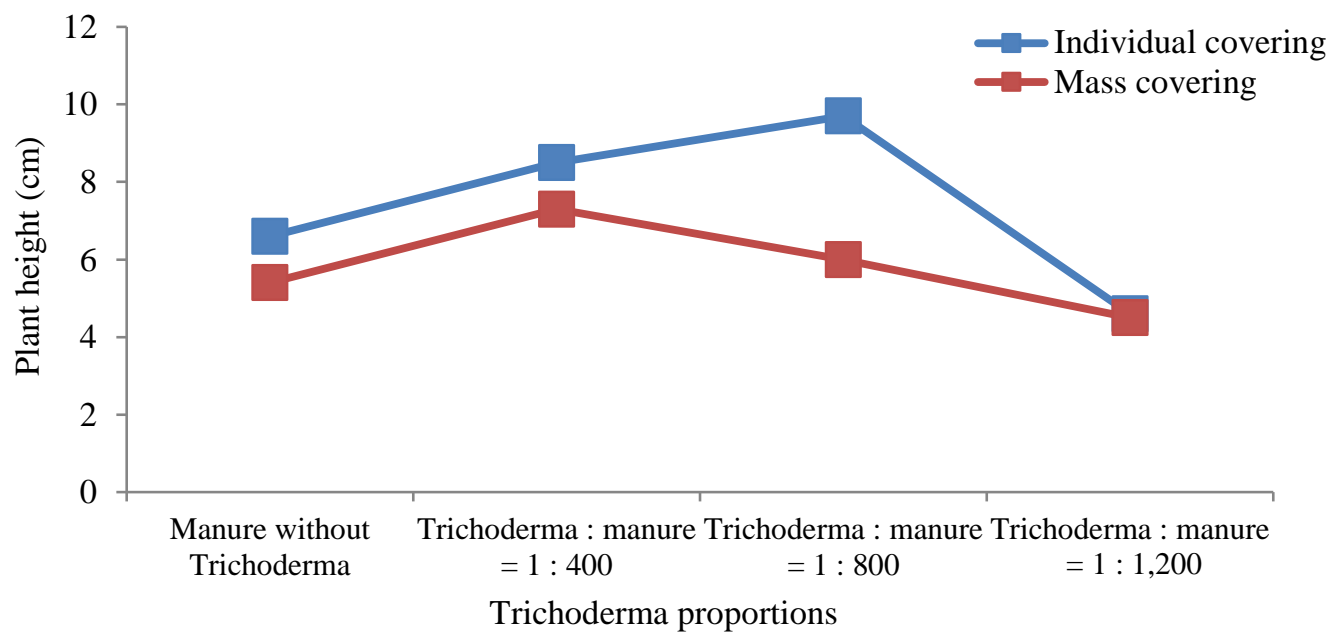

Figure 1. The data of plant height interaction between covering types with Trichoderma proportions 


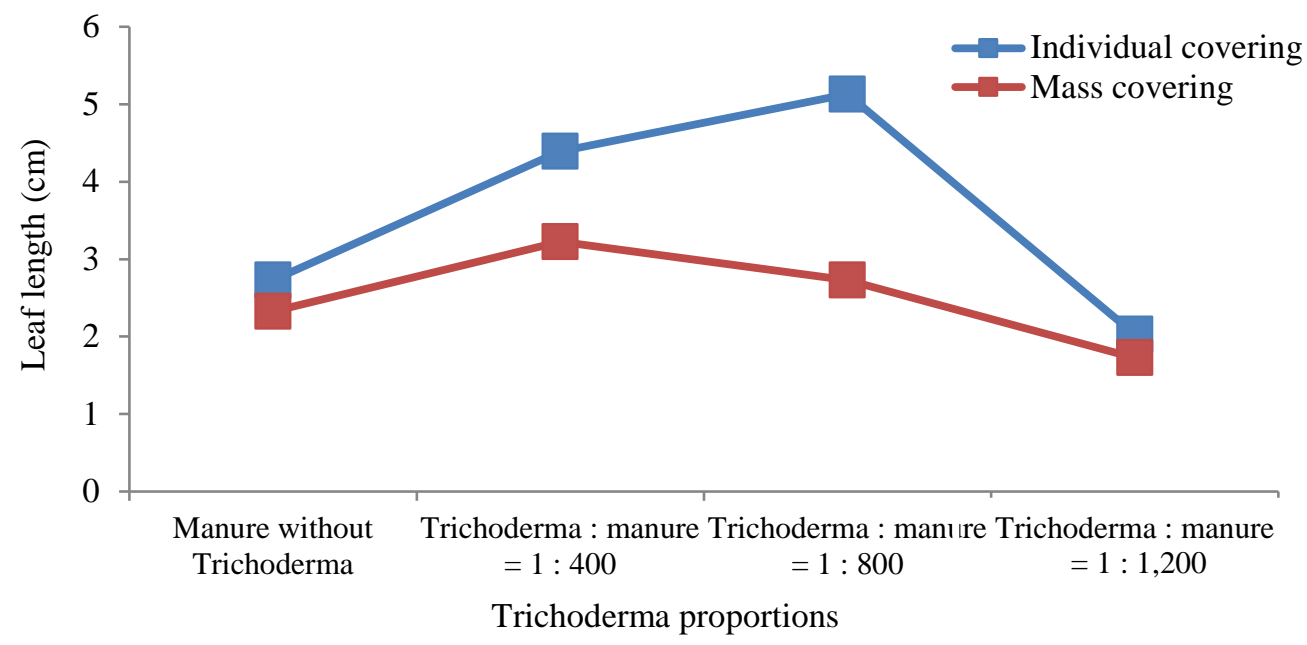

Figure 2. The data of interaction between leaf length and covering types with Trichoderma proportions

The interaction between addition of Trichoderma proportions and covering types significantly affect the leaf length of banana plantlets cv. Barangan at $p<0.05$ (Figure 2). The best treatment for leaf length was found in the interaction between Trichoderma sp. : manure $=1$ : $800(\mathrm{w} / \mathrm{w})$ and individual covering $(5.1 \mathrm{~cm})$. However, this result was not significantly different with the result shown in the treatment with Trichoderma sp. : manure $=1: 400(\mathrm{w} / \mathrm{w})$ in individual covering. In contrast, the lower leaf lengths were found in several treatments, especially control treatment and Trichoderma sp.
: manure $=1: 1,200(\mathrm{w} / \mathrm{w})$ for both in individual covering and mass covering.

As shown in Table 2, the treatments given did not show interaction between the addition of Trichoderma proportion and covering type. Plantlets in individual covering significantly had wider leaves compared to mass covering, while the additional Trichoderma sp. : manure $=1: 400$ $(\mathrm{w} / \mathrm{w})$ resulted in wider leaves than the other treatments. However, this result did not significantly differ with the result indicated in the treatment with the addition of Trichoderma sp. : manure $=1: 800(\mathrm{w} / \mathrm{w})$.

Table 2. The number of leaves, leaf width and root length of banana plantlets cv. Barangan after twoweek acclimatization with two covering types and four Trichoderma sp. proportions. The values in columns followed by the same letter are not significantly different at $p<0.05$

\begin{tabular}{|c|c|c|c|}
\hline Treatments & Number of leaves & Leaf width $(\mathrm{cm})$ & Root length $(\mathrm{cm})$ \\
\hline \multicolumn{4}{|l|}{ Covering types } \\
\hline - Individual covering & $3.1 \pm 0.18 \mathrm{a}$ & $1.5 \pm 0.13 \mathrm{a}$ & $3.8 \pm 0.46 a$ \\
\hline - Mass covering & $2.4 \pm 0.17 b$ & $1.1 \pm 0.06 b$ & $3.2 \pm 0.24 \mathrm{a}$ \\
\hline \multicolumn{4}{|l|}{ Trichoderma compositions } \\
\hline $\begin{array}{l}\text { - Manure without Trichoderma } \\
\text { addition }\end{array}$ & $2.7 \pm 0.15 \mathrm{ab}$ & $1.2 \pm 0.07 \mathrm{~b}$ & $2.4 \pm 0.25 b$ \\
\hline $\begin{array}{l}\text { - Trichoderma }: \text { manure }=1: 400 \\
(\mathrm{w} / \mathrm{w})\end{array}$ & $3.3 \pm 0.21 \mathrm{a}$ & $1.7 \pm 0.22 \mathrm{a}$ & $4.4 \pm 0.37 \mathrm{a}$ \\
\hline $\begin{array}{l}\text { - Trichoderma }: \text { manure }=1: 800 \\
(\mathrm{w} / \mathrm{w})\end{array}$ & $2.8 \pm 0.24 \mathrm{ab}$ & $1.3 \pm 0.11 \mathrm{ab}$ & $4.6 \pm 0.56 \mathrm{a}$ \\
\hline $\begin{array}{l}\text { - Trichoderma }: \text { manure }=1: 1,200 \\
(\mathrm{w} / \mathrm{w})\end{array}$ & $2.1 \pm 0.30 \mathrm{~b}$ & $1.0 \pm 0.09 b$ & $2.6 \pm 0.33 b$ \\
\hline
\end{tabular}

Note: (-) showing no interaction, meaning that it is followed by different letter and shows significant difference according to DNMRT at $p<0.05$; data are means of four replicates with standard error

Both leaf length and leaf width contribute to the total leaf area. Better results in leaf length and leaf width mean better leaf area. Leaf area had a significant part in plant growth and development 
due to leaf function in photosynthesis process (Gardner et al., 1991). Beside the genetic factor, environmental factors determined the leaf area of plant (Srihartanto and Indradewa, 2019). In this experiment, banana plantlets cv. Barangan were treated in different environmental conditions such as media mixtures and types of covering. Different environmental condition contributed to various leaf length and leaf width.

Table 2 shows the numbers of leaves of banana plantlets var. Barangan after the treatments. Treatment combinations of Trichoderma addition proportions and covering types significantly affected the numbers of leaves of banana plantlets; however, no interaction between those treatment factors were exposed. Similarly, as previous parameter, individual covering also resulted in better numbers of leaves compared to mass covering. The addition of Trichoderma : manure $=1: 400(\mathrm{w} / \mathrm{w})$ produced the highest numbers of leaves compared to the other Trichoderma proportions.
In normal condition, the leaves of banana cv. Cavendish will grow within 8-10 days (Robinson and Sáuco, 2009). Gutiarrez-Miceli et al. (2008) reported orchid treated with $T$. harzianum produced higher number of leaves compared to that treated without $T$. harzianum. In line with this result, Murunde et al. (2018) reported that banana plants cv. Cavendish treated with Trichoderma yielded more leaves compared to the control.

Table 2 also presents that the covering types did not affect the root length of plantlets. In contrast, the proportions of Trichoderma addition significantly affected the root length of banana plantlets. The addition of Trichoderma sp. : manure $=1: 400(\mathrm{w} / \mathrm{w})$ and Trichoderma $\mathrm{sp}$. : manure $=1: 800(\mathrm{w} / \mathrm{w})$ produced longer root than other treatments. The association between plant and beneficial microbes could support the nutrient uptake that resulted in longer root and higher number of lateral roots (Thomas et al., 2010). Even, Chandra et al. (2010) showed that the application of $T$. harzianum could trigger the root growth in in vivo condition.

\section{Component Plot in Rotated Space}

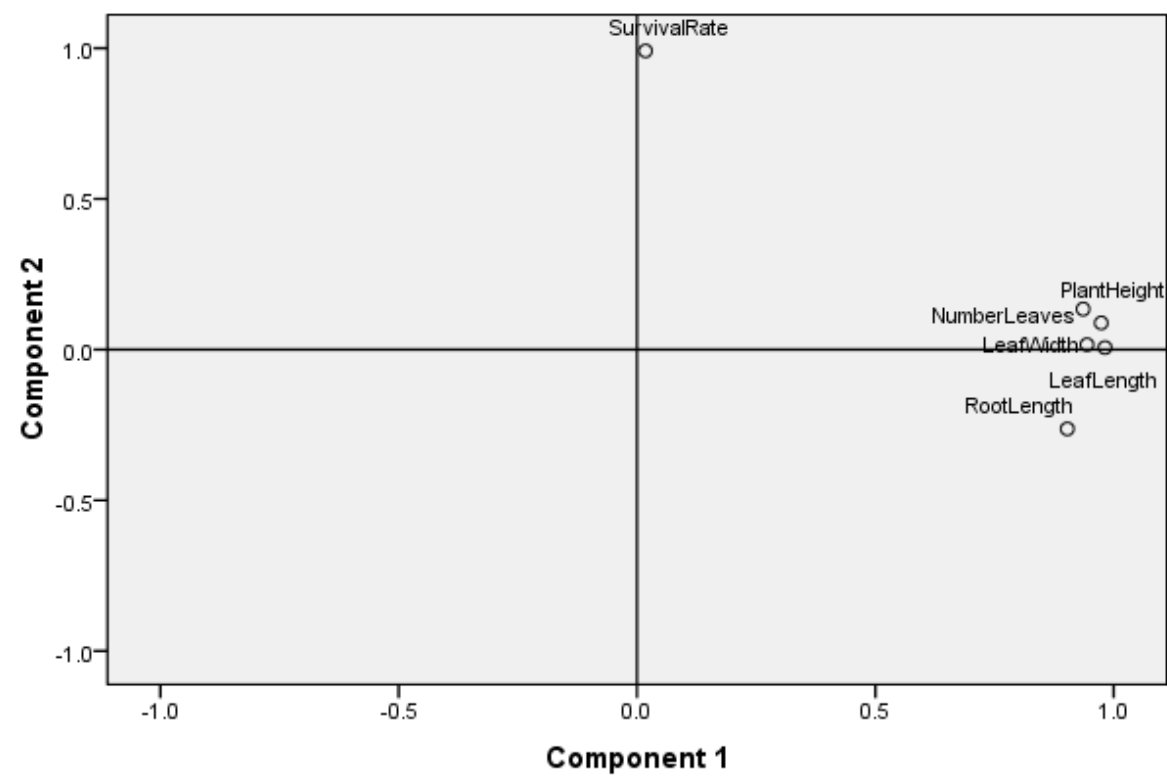

Figure 3. The Principal Component Analysis (PCA) test of six parameters of plants based on the covering types and Trichoderma proportions

The result from principal component analysis showed that the first principal component (PC1) accounted for $75 \%$ of the total variance, while the second principal component accounted for $18 \%$ an additional variance. PC1 represented the variation in five growth parameters of plant such as plant height, leaf length, leaf width, number of leaves and root length. PC2 only represented variation in survival rate of plant (Figure 3 ). The result showed that five growth parameters (plant 
height, leaf length, leaf width, number of leaves and root length) correlated each other. Based on leaf-height-seed (LHS) scheme, Westoby (1998) explained that three plant traits (leaf traits, plant height and seed mass) were fundamental for plant growth. These traits also correlated to and integrated with the other plant traits, for example root traits (Westoby, 1998; Laughlin et al., 2010).

The combination of both factors indeed affected the growth of banana plantlets. Several treatment combinations between the proportion of Trichoderma sp. addition and covering types provided better growth of banana plantlets $\mathrm{cv}$. Barangan compared to the control treatment. The treatment combinations between the addition of Trichoderma sp. : manure $=1: 400(\mathrm{w} / \mathrm{w})$ and Trichoderma $\mathrm{sp}$. : manure $=1: 800(\mathrm{w} / \mathrm{w})$ with individual covering type were the best combinations for the growth of plantlets. These combinations provided the best growth parameters comprising plant height, leaf length, leaf width and the number of leaves of banana plantlets cv. Barangan.

The application of Trichoderma improved the survival rates of plantlets and promoted better growth performance in other plant traits, such as stem diameter, fresh and dry weight of plants in the acclimatization process (Thomas et al., 2010; Murunde et al., 2018). The benefit of using this antagonistic fungus species in in vitro plantlets is due to the ability of this species to enhance nutrients and water uptake from growth media (Thomas et al., 2010; Colla et al., 2015). Thomas et al. (2010) also found that plants treated with Trichoderma produced higher contents of nitrogen and potassium compared to control plants.

In addition to those benefits, Trichoderma gave other benefits in agriculture. The application of Trichoderma could suppress the phytopathogenic infections in several plants (Benítez et al., 2004; El_Komy et al., 2015; Kushwaha et al., 2019). Banana cv. Barangan, which was used in this study is one of susceptible banana cultivars to Fusarium infections. Therefore, the application of Trichoderma since the acclimatization stage is expected to be able to prepare healthy plant of banana cv. Barangan before being planted in the field. Several Trichoderma strains are used as biofertilizers and myco-biocontrol agents (Mahfut et al., 2019; Silva et al., 2019). Some of them also help in plant growth and development in unfavorable environmental conditions (Benítez et al., 2004; Brotman et al., 2013; ContrerasCornejo et al., 2014; Zhao et al., 2014).

\section{CONCLUSIONS}

The best treatment to enhance plantlet growth during the acclimatization process was the addition of Trichoderma sp. : manure with $1: 400$ (w/w) proportion and individual covering. The addition of Trichoderma sp. 1: 400 produced similar plantlet performances with the treatments using higher Trichoderma sp. contents, but it used lower Trichoderma sp. proportion. Based on this research, we recommend the use of Trichoderma sp. : manure proportion $=1: 400(\mathrm{w} / \mathrm{w})$ in combination with individual covering to improve banana plantlet growth during acclimatization.

\section{ACKNOWLEDGEMENT}

I would like to thank Ida Fitrianingsih as the technician for helping us during the experiments.

\section{REFERENCES}

Al-Ani, L. K. T. (2018). Trichoderma: Beneficial role in sustainable agriculture by plant disease management. In: Egamberdieva D., Ahmad P. (eds) Plant Microbiome: Stress Response. Microorganisms for Sustainability, vol 5, pp. 105-126. Springer, Singapore. https:// doi.org/10.1007/978-981-10-5514-0_5

Bag, N., Kumar, A., Nandi, S. K., Pandey, A., \& Palni, L. M. S. (2001). Efficient rooting and biological hardening of tissue culture raised tea (Camellia sinensis (L.) O. Kuntze) plants. Proceedings International Conference on $O$ Cha (Tea) Culture and Science. Session II: Production., 132-155. Shizuoka, Japan. Retrieved from https://www.researchgate.net/ publication/232613426_Efficient_rooting_an d_biological_hardening_of_tissue_culture_rai sed_tea_Camellia_sinensis_L_O_Kuntze_pla nts

Barari, H. (2016). Biocontrol of tomato Fusarium Wilt by Trichoderma species under in vitro and in vivo conditions. Cercetări Agronomice În Moldova, 49(1), 91-98. https://doi.org/ 10.1515/cerce-2016-0008

Benítez, T., Rincón, A. M., Limón, M. C., \& Codon, A. C. (2004). Biocontrol mechanisms of Trichoderma strains. International 
Microbiology, 7(4), 249-260. Retrieved from https://pubmed.ncbi.nlm.nih.gov/15666245/

Brotman, Y., Landau, U., Cuadros-Inostroza, A., Takayuki, T., Fernie, A. R., Chet, I., Viterbo, A., \& Willmitzer, L. (2013). Trichodermaplant root colonization: escaping early plant defense responses and activation of the antioxidant machinery for saline stress tolerance. PLoS Pathogens, 9(3), e1003221. https://doi.org/10.1371/journal.ppat.1003221

Castillo, A. G., Puig, C. G., \& Cumagun, C. J. R. (2019). Non-synergistic effect of Trichoderma harzianum and Glomus spp. in reducing infection of Fusarium Wilt in banana. Pathogens, 8(43), 1-8. https://doi.org/ 10.3390/pathogens 8020043

Chandra, S., Bandopadhyay, R., Kumar, V., \& Chandra, R. (2010). Acclimatization of tissue cultured plantlets: from laboratory to land. Biotechnology Letters, 32(9), 1199-1205. https://doi.org/10.1007/s10529-010-0290-0

Colla, G., Rouphael, Y., Di Mattia, E., El-Nakhel, C., \& Cardarelli, M. (2015). Co-inoculation of Glomus intraradices and Trichoderma atroviride acts as a biostimulant to promote growth, yield and nutrient uptake of vegetable crops. Journal of the Science of Food and Agriculture, 95(8), 1706-1715. https://doi. org/10.1002/jsfa.6875

Contreras-Cornejo, H. A., Macías-Rodríguez, L., Alfaro-Cuevas, R., \& López-Bucio, J. (2014). Trichoderma spp. improve growth of arabidopsis seedlings under salt stress through enhanced root development, osmolite production, and $\mathrm{Na}+$ elimination through root exudates. Molecular Plant-Microbe Interactions, 27(6), 503-514. https://doi.org/ 10.1094/MPMI-09-13-0265-R

Damayanti, T. A., Pardede, H., \& Mubarik, N. R. (2007). Utilization of root-colonizing bacteria to protect hot-pepper against tobacco mosaic tobamovirus. HAYATI Journal of Biosciences, 14(3), 105-109. https://doi.org/10.4308/hjb. 14.3.105

El_Komy, M. H. El, Saleh, A. A., Eranthodi, A., \& Molan, Y. Y. (2015). Characterization of novel Trichoderma asperellum isolates to select effective biocontrol agents against tomato Fusarium Wilt. The Plant Pathology
Journal,31(1), 50-60. https://doi.org/10.5423/ PPJ.OA.09.2014.0087

Eliza, Emilda, D., Hermanto, C., \& Djatnika, I. (2014). Patent No. IDP 000037067. Indonesia: Direktorat Jenderal Kekayaan Intelektual.

Emilda, D., Sutanto, A., Sukartini, \& Jumjunidang. (2020). Application of salicylic acid to induce disease resistance against Fusarium Wilt on banana. IOP Conference Series: Earth and Environmental Science, 468 , 012026. https://doi.org/10.1088/1755-1315/46 8/1/012026

FAO. (2019). Banana facts and figures. Retrieved from http://www.fao.org/economic/est/est-co mmodities/bananas/bananafacts/en/\#.XcPBq DNKJIV

Gardner, F. P., Pearce, R. B., \& Mitchell, R. L. (1991). Physiology of crop plant (fisiologi tanaman budidaya, alih bahasa: H. Susilo). Jakarta: UI-Press.

Gutiarrez-Miceli, F. A., Ayora-Talavera, T., Abud-Archila, M., Salvador-Figueroa, M. Adriano-Anaya, L., Hernandez, M. A., \& Dendooven, L. (2008). Acclimatization of micropropagated orchid Guarianthe skinnerii inoculated with Trichoderma harzianum. Asian Journal of Plant Sciences, 7(3), 327330. http://dx.doi.org/10.3923/ajps.2008.327. 330

Hallam, D. (1995). The world banana economy. In: Gowen S. (eds) Bananas and plantains. World Crop Series. Springer, Dordrecht. https://doi.org/10.1007/978-94-011-0737-2_ 19

Hazarika, B. N. (2003). Acclimatization of tissuecultured plants. Current Science, 85(12), 1704-1712. Retrieved from https://www. jstor.org/stable/24109975

Khan, B., Akash, Z., Asad, S., Javed, N., Rajput, N. A., Jabbar, A., Din, W. U., \& Atif, R. M. (2017). Antagonistic potential of Trichoderma harzianum against Fusarium oxysporum fsp cubense associated with Panama Wilt of banana. Pakistan Journal of Phytopathology, 29(01), 111-116. https://doi.org/10.33866/ phytopathol.029.01.0299

Kumar, R., Ahmed, M. F., Mir, H., Mehta, S., \& Sohane, R. K. (2019). Study on in vitro 
establishment and callus Induction in banana cv. Grand Naine. Current Journal of Applied Science and Technology, 33(3), 1-5. https://doi.org/10.9734/CJAST/2019/v33i330 073

Kushwaha, R. K., Singh, S., Pandey, S. S., Rao, D. V., Nagegowda, D. A., Kalra, A., \& Babu, C. S. V. (2019). Compatibility of inherent fungal endophytes of Withania somnifera with Trichoderma viride and its impact on plant growth and withanolide content. Journal of Plant Growth Regulation, 38, 1228-1242. https://doi.org/10.1007/s00 344-019-09928-7

Lahav, E. (1995). Banana nutrition. In: Gowen S. (eds) Bananas and plantains, (pp. 258-316). World Crop Series. Springer, Dordrecht. https://doi.org/10.1007/978-94-011-0737-2_ 11

Laughlin, D. C., Leppert, J. J., Moore, M. M., \& Sieg, C. H. (2010). A multi-trait test of the leaf-height-seed plant strategy scheme with 133 species from a pine forest flora. Functional Ecology, 24(3), 493-501. https:// doi.org/10.1111/j.1365-2435.2009.01672.x

Mahfut, Daryono, B. S., Indrianto, A., \& Somowiyarjo, S. (2019). Effectiveness test of orchid mycorrhizal isolate (Ceratorhiza and Trichoderma) Indonesia and its role as a biofertilizer. Annual Research \& Review in Biology, 33(4), 1-7. https://doi.org/10.9734/ $\operatorname{arrb} / 2019 / \mathrm{v} 33 i 430127$

Martínez-Medina, A., Roldán, A., \& Pascual, J. A. (2011). Interaction between arbuscular mycorrhizal fungi and Trichoderma harzianum under conventional and low input fertilization field condition in melon crops: growth response and Fusarium Wilt biocontrol. Applied Soil Ecology, 47(2), 98105. https://doi.org/10.1016/j.apsoil.2010.11. 010

Murashige, T., \& Skoog, F. (1962). A revised medium for rapid growth and bio assays with tobacco tissue cultures. Physiologia Plantarum, 15(3), 473-497. https://doi.org/ 10.1111/j.1399-3054.1962.tb08052.x

Murunde, R., Muriithi, I., \& Wainwright, H. (2018). Potential use of endophytic bacterial and fungi as bio fertilizer to promote plant growth in tissue culture banana. Journal of Molecular Studies and Medicine Research, 3(2), 148-160. Retrieved from https:// www.researchgate.net/publication/336892397 _Potential_use_of_endophytic_bacterial_and_ fungi_as_bio_fertilizer_to_promote_plant_gr owth_in_tissue_culture_banana

Nainggolan, P., Harahap, A. D., Napitupulu, B., Karokaro, S., \& Rajagukguk, J. (1998). Improving of banana var. Barangan technological package in Deli Serdang, Medan (Indonesia). Prosiding Seminar Nasional Ekspose Hasil Penelitian Dan Pengkajian Teknologi Pertanian. Medan, Indonesia: BPTP Sumatera Utara. Retrieved from https://agris.fao.org/agris-search/search. do?recordID=ID2001000861

Ortas, İ., Rafique, M., Akpinar, C., \& Kacar, Y. A. (2017). Growth media and mycorrhizal species effect on acclimatization and nutrient uptake of banana plantlets. Scientia Horticulturae, 217, 55-60. https://doi.org/ 10.1016/j.scienta.2017.01.025

Pandey, A., Palni, L. M. S., \& Bag, N. (2000). Biological hardening of tissue culture raised tea plants through rhizosphere bacteria. Biotechnology Letters, 22(13), 1087-1091. https://doi.org/10.1023/A:1005674803237

Poerba, S., Martanti, D., \& Ahmad, F. (2018). Deskripsi pisang koleksi pusat penelitian biologi LIPI. Retrieved from https://eservice.lipipress.lipi.go.id/press/catalog/view/ 181/170/346-1)

Pospóšilová, J., Tichá, I., Kadleček, P., Haisel, D., \& Plzáková, S̆. (1999). Acclimatization of micropropagated plants to ex vitro conditions. Biologia Plantarum, 42(4), 481497. https://doi.org/10.1023/A:10026882087 58

Robinson, J. C., \& Sáuco, V. G. (2009). Weaning (acclimatization) of in vitro-produced banana plants. Fruits, 64(5), 325-332. https://doi.org/ 10.1051/fruits:2009026

Shah, S., Thapa, B. B., Chand, K., Pradhan, S., Singh, A., Varma, A., Sen Thakuri, L., Joshi, P., \& Pant, B. (2019). Piriformospora indica promotes the growth of the in-vitro-raised Cymbidium aloifolium plantlet and their acclimatization. Plant Signaling \& Behavior, 
14(6), 1596716. https://doi.org/10.1080/1559 2324.2019.1596716

Silva, B. B., Banaay, C. G., \& Salamanez, K. (2019). Trichoderma-induced systemic resistance against the scale insect (Unaspis mabilis Lit \& Barbecho) in lanzones (Lansium domesticum Corr.). Agriculture \& Forestry/ Poljoprivreda $i$ Sumarstvo, 65(2), 59-78. https://doi.org/10.17707/AgricultForest.65.2. 05

Singh, B. N., Singh, A., Singh, G. S., \& Dwivedi, P. (2015). Potential role of Trichoderma asperellum T42 strain in growth of pea plant for sustainable agriculture. Journal of Pure and Applied Microbiology, 9(2), 1069-1074. Retrieved from https://microbiologyjournal. org/potential-role-of-trichoderma-asperellumt42-strain-in-growth-of-pea-plant-for-sustaina ble-agriculture/

Srihartanto, E., \& Indradewa, D. (2019). Effects of planting time and cultivar on leaf physiology and seed yield of soybean (Glycine max (L.) Merr). Caraka Tani: Journal of Sustainable Agriculture, 34(2), 115-127. https://doi.org/10.20961/carakatani.v34i2.289 74

Tenkouano, A., Hauser, S., Coyne, D., \& Coulibaly, O. (2006). Clean planting materials and management practices for sustained production of banana and plantain in Africa. Chronica Horticulturae, 46(2), 14-18. Retrieved from https://www.researchgate.net/ publication/284108336_Clean_planting_mate rials_and_management_practices_for_sustain ed_production_of_banana_and_plantain_in_ Africa

Thomas, J., Ajay, D., Kumar, R. R., \& Mandal, A. K. A. (2010). Influence of beneficial microorganisms during in vivo acclimatization of in vitro-derived tea (Camellia sinensis) plants. Plant Cell, Tissue and Organ Culture (PCTOC), 101(3), 365-370. https://doi.org/ 10.1007/s11240-010-9687-7

Westoby, M. (1998). A leaf-height-seed (LHS) plant ecology strategy scheme. Plant and Soil, 199(2), 213-227. https://doi.org/10.1023/ A:1004327224729

Winarto, B., \& Prama Yufdy, M. (2017). Establishment of in vitro propagation protocol of Gerbera Jamesonii bolus ex hook f.: explant and media selection to plantlet acclimatization. Journal of Agricultural Science, 28(1), 32-40. http://dx.doi.org/10.15159/jas.17.03

Wong, K. F., Suhaimi, O., \& Fatimah, K. (2017). On-farm grower-friendly nursery technique for acclimatization of tissue-cultured banana seedlings. Asian Journal For Poverty Studies (AJPS), 3(2), 146-151. https://doi.org/ 10.33369/ajps.v3i2.2692

Zhao, L., Wang, F., Zhang, Y., \& Zhang, J. (2014). Involvement of Trichoderma asperellum strain $\mathrm{T} 6$ in regulating iron acquisition in plants. Journal of Basic Microbiology, 54(S1), S115-S124. https://doi. org/10.1002/jobm.201400148 